\title{
Growth potential of energy sector reforms: new evidence on EU and Southeast European countries by exploring impact on electricity generation ${ }^{* 1}$
}

\author{
Nela Vlahinić Lenz $z^{2}$, Vedran Prša ${ }^{3}$
}

\begin{abstract}
The aim of this research is to investigate the impact of energy sector reforms on electricity generation and thus economic growth in EU and Southeast European countries. The paper aims at clarifying whether the impact of energy sector reforms on generation efficiency differs among countries according to their level of development and regional characteristics. Our hypothesis is that the EU reform model is not appropriate for all Member States and Southeast European countries since it does not improve efficiency in electricity generation in all countries and therefore, it can hamper economic growth. For testing the defined hypothesis the panel regression model with fixed effects has been used. The research results show that unlike in the EU-15 (old Member States), energy sector reforms in the EU-12 (new Member States), and selected Southeast European countries (Energy Community contracting parties) have no significant impact on electricity transmission and distribution losses. These evidences imply that the uniform EU reform model does not improve efficiency of electricity generation in less developed countries. On the contrary it can even hamper economic growth and therefore it cannot be appropriate for all Member States. The reason lies in the fact that successful reform model requires adequate level of institutional resources that are missing in most transition and post-transition countries.
\end{abstract}

Key words: energy sector reforms, electricity generation, economic growth, transmission and distribution losses, EU, Southeast Europe

JEL classification: Q43, Q48, L94, 98

* Received: 10-11-2015; accepted: 15-12-2015

1 This work has been fully supported by Croatian Science Foundation under the project IP-2013-11-2203 and has been supported in part by the University of Rijeka under the project number 13.02.1.3.05.

2 Full Professor, University of Rijeka, Faculty of Economics, I. Filipovića 4, 51000 Rijeka, Croatia. Scientific affiliation: macroeconomics, energy economics. Phone: +385 51355 111. E-mail: nela@efri.hr.Web site: https://www.efri.uniri.hr/personnel/redoviti-profesor/vlahinic-lenz-nela.

3 PhD, JP Elektroprivreda BiH - Subsidiary "Elektrodistribucija” Bihać, Krupska bb, 77000 Bihać, Bosnia and Herzegovina. Scientific affiliation: energy economics. Phone: +387 37226 308. E-mail: vedranpra@yahoo.com. 


\section{Introduction}

Long term, sustainable economic growth needs a sustainable electricity supply. In order to accomplish this goal, good economic governance incorporating energy policy should implement reforms that will increase economic efficiency and social prosperity. 2015 has been a turbulent year for the energy sector - geopolitical uncertainties, slowing economic growth and the drop in oil prices are affecting electricity sectors around the world. In this context, effective energy reforms are more important than ever to drive competitiveness and economic growth. EU as the major energy importer and Southeast European countries that have become Energy Community contracting parties face some of the greatest challenges in transforming its electricity sector.

Improvement in efficiency constitutes one of the main aims in any electricity sector reform program. It is typically argued that, even in the short run, the reform process introduces competition, which in turn encourages economic units with the lowest costs to operate in the market. Overall, it is expected that the introduction of reforms in the electricity sector leads to higher efficiency levels and thus stimulates economic growth. There is a growing body of literature that proved a strong evidence on correlation and causal relationship between electricity production and economic growth in developed and developing countries (Morimoto and Hope (2004); Yoo and Kim (2006); Ghosh (2009); Lean and Smyth (2010); Sarker and Alam (2010); Bayraktutan et al. (2011); Zeshan (2013)). Therefore it will not be a subject of research in this paper. However, analyzing the impact of reforms on the most important segment of electricity sector - electricity generation, one could estimate the impact of the reforms on economic growth. A reform process is a set of multidimensional activities with interacting factors and impacts. At one level, reform measures involve structural and organizational changes in the energy sector, while at another, broader, level they aim to establish the appropriate institutional setting such as legislation and new regulatory agencies. Although there are differences in individual reforms across the world, the EU Member States have implemented the same reform model. Generally, it involves a combination of key elements: 1) regulatory reforms and the establishment of an independent regulatory authority, 2) restructuring (vertical and horizontal unbundling), 3) market liberalization (competition on the wholesale and retail market) and 4) privatization (new entries by private firms and privatization of state companies).

The reforms in the sector started in the early 1990s, which has limited the existing literature due to the relatively short span of time, especially in econometric studies that require a large number of observations. Moreover, the literature lacks adequate cross-testing of most of the hypotheses and lacks data conducting appropriate panel-data analysis. Though there are a number of papers dealing with the results of the reforms in developed countries using cross-country models, the number of those 
focusing on transition and developing economies is rather small, especially those using panel data analysis. Therefore, there is a strong need for a new systematic analysis that would include the EU countries and the Southeast European countries in addition to a broader range of issues related to energy sector reforms within a longer time frame. As far as is known, this is the first analysis in the field performed on Southeast European countries.

The aim of this research is to investigate the effects of the reforms conducted in the energy sector on electricity generation and its efficiency measured by installed electricity generation capacity and network (transmission and distribution) losses, in order to predict the growth potential of the reforms. Since the research intends to prove that the EU reform model cannot be appropriate for all Member States and Southeast European countries as Energy Community contracting parties, the paper aims at clarifying whether the impact of the energy sector reform on generation efficiency differs among countries according to their level of development and regional characteristics. Empirical econometric models are estimated and then analyzed to observe the effects of the energy market reforms on electricity generation and electricity network losses. The data used in our analysis is net electricity generation per capita (in $\mathrm{GWh} /$ million people), net installed electricity generation capacity per capita (in GW/million people), net electricity generation per employee (in GWh/million people) and electricity network (transmission and distribution) losses (\% of output) as dependent variables. The explanatory (independent) variable is the 'electricity market reform' variable computed in accordance with methodology developed by Erdogdu (2011) that covers the key elements of reforms. Our hypothesis is that the EU reform model is not appropriate for all Member States and Southeast European countries that are Energy Community contracting parties since it does not improve efficiency in electricity generation in all countries and therefore it can even hamper economic growth.

The paper is organized as follows. Section 2 gives a literature review on economic effects of reforms conducted in the energy sector with special reference to electricity sector. Section 3 describes the econometric methodology, Section 4 describes data and presents the obtained empirical results. Section 5 discusses the results and the final section contains the conclusions.

\section{Literature review}

Owing to the fact that the electricity sector operates within the wider economic and institutional system, it can be expected that the reform results are strongly influenced by overall macroeconomic framework and vice versa, reform results have considerable impact on economic growth. Institutional aspects of the sector such is regulatory regime also affects the dynamics and the results of reforms and 
consequently economic growth. Broadly, the findings of the literature on electricity reforms and their impact on economic efficiency and growth may be summarized in several fields regarding the impacts of particular reform measures on economic outcomes.

Effects of competition and market liberalization have been the research interest in many papers. According to Zhang et al. (2002), competition leads to higher output, capacity and labor productivity in developing countries. However, they also found that competition has no statistically significant impact on electricity price ratio between industrial and residential consumers in developing countries. Steiner (2001) found that unbundling of generation and transmission in developed countries results in higher capacity utilization rates and lower reserve margins. Moreover, according to her study, unbundling does not lead to lower electricity prices but is positively correlated with cost-reflective pricing. Hattori and Tsutsui (2003) found that 'legal unbundling' leads to higher electricity prices, and that the introduction of wholesale power pool is associated with higher electricity prices.

The question of energy sector reforms' impact on electricity prices has been widely analysed because of its important effect on economic welfare. Thomas (2006) rejects the widespread beliefs that energy market reforms and liberalization in the European Union result in lower electricity prices for consumers. According to Thomas, price reductions occurred mostly in the period 1995-2000 before liberalization was effective in most of the EU countries. These price reductions were mostly the result of fossil fuel price movements, relatively low costs, changes in regulatory practices and technological innovations. After 2000, electricity prices have risen sharply both for residential and industrial consumers in the European Union. Furthermore, he suggests that the EU reform model's real test is whether it can deliver timely investment to meet the emerging investment gap following the elimination of short run inefficiency and initially high reserve margins (Pollitt 2007). Using a panel data for the EU-15 countries over the period 1978-2005, Fiorio et al. (2007) investigate the impact of electricity market reform on household electricity prices. According to their results, entry and vertical integration do not seem to lower electricity prices, while public ownership leads to lower electricity prices. Using a panel data for 83 countries covering the period 1985-2002, Nagayama (2007) tries to answer if and how individual reforms steps impact electricity prices for countries in Eastern Europe, the former Soviet Union and Latin America. Their research findings also suggest that the introduction of a wholesale spot market and unbundling of generation and transmission do not lead to a reduction in electricity prices. Contrary to their expectations, these two individual reforms steps resulted in an increase of electricity prices. In addition, Nagayama found that the introduction of foreign independent power producers (IPP), competition in electricity retail markets and privatization have led to a reduction in electricity prices in some, but not in all of the regions. In his second 
paper, Nagayama (2009) wants to clarify whether the effects of energy sector reforms are systematically different among various country groups in relation to level of development and region. Nagayama observed the impact of electricity prices on the implementation of a liberalization model. In this study, a panel data from 78 countries in four regions is used for the period 1985-2003. The four regions include: developed countries, Latin America, Asian developing countries, Eastern Europe and the former Soviet Union. According to research findings, higher electricity prices have a significant impact on government decision to adopt liberalization models. The research findings again suggest that the development of liberalization models in the electricity sector is not necessarily associated with lower electricity prices. Quite on the contrary, electricity prices have risen in every market model.

Another research field is oriented towards the effects of regulation. An effective regulatory system is crucial for both investor confidence and consumer protection. A well-designed regulatory system should protect consumers from monopoly abuse and provide investors with protection from arbitrary political action. In addition, one of the main aims of a well-designed regulatory system is to provide investors with incentives to promote efficient operation and investments (Laffont and Tirole 1993). According to Parker at.al. (2007), effective regulation achieves the social welfare goals set down by the government for the regulatory authority. In developing countries, the social welfare objectives of regulation are likely to be not simply concerned with the pursuit of economic efficiency but with wider goals to promote sustainable development and poverty reduction. They tested the hypothesis that the efficiency and quality of regulation affects the economic performance of an economy and conclude that the impact of regulatory institutions on economic growth will depend on both the efficiency of the regulatory policies and instruments that are used and the quality of the governance processes that are practised by the regulatory authorities. Under risky regulatory conditions, private operators will be unwilling to invest and will produce less (Gupta and Sravat 1998; Holburn 2001) and consequently it will lower economic growth. At the same time, clearly stated regulatory rules within a well-defined regulatory framework can be expected to reduce 'regulatory risk' and provide incentives for private investment which is the main objective when independent regulatory bodies are established (Zhang et al., 2008). Therefore, a carefully designed regulation can be seen as a key component of a successful reform that would stimulate economic activity and welfare. Although the attitude of economic theory towards a positive impact of regulatory quality on the success of the electricity sector is clear, there are only a few empirical studies dealing with this issue focusing electricity sector and they are mainly focused on the efficiency of electricity generation, and not the sector as a whole. The lack of empirical, quantitative research of this issue is mostly the result of difficulties in quantifying regulatory quality parameters. However, there are several papers that have identified the causal effects of better governance and overall institutional 
design on higher per capita incomes in the long run (Barro, 1997; Hall and Jones, 1999; Kauffman and Kraay, 2002). Olson et al. (1998) find that productivity growth is higher in countries with better institutions and quality of governance. Kauffman and Kraay (2002) relate the quality of governance to economic outcomes using a data set covering 175 countries for the period 2000-01.

The effects of privatization on economic performance and economic growth have been investigated in many papers but their conclusions are ambiguous. Bortolotti et al. (1998) conclude that effective regulation is crucial to the success of privatization and its impact on economic growth. They use data on the privatization of electricity generation in 38 countries (both developed and developing) between 1977 and 1997. Using a panel dataset of 19 OECD countries for the period 1987-1996, Steiner (2001) tests the impact of regulatory environment, the degree of vertical integration and the degree of private ownership on electricity prices and overall efficiency. The four main variables in her panel data analysis are: electricity price per unit, industrial to residential electricity price ratio, generation capacity utilization ratio and generation reserve margin. The first two variables represent the competitive aspects of reform, while the second two examine the reform's cost efficiency. Some elements of the electricity sector reform are tested separately in this study: the introduction of a wholesale power pool, unbundling of transmission system operator, third party access to transmission grid and privatization. The results of the study show that privatization leads to higher electricity prices and industrial to residential electricity price ratio. Moreover, privatization has no significant impact on cost efficiency. According to Steiner, there is a significantly positive relationship between the utilization rate on one hand, and private ownership and unbundling of generation and transmission on the other. Steiner also concludes that privatization leads to higher operating efficiency and capital utilization in developed countries. Using a similar analysis, but over a longer period of time, 1987-1999, Hattori and Tsutsui (2004) test the impact of unbundling of transmission from generation, third party access, the existence of a wholesale market and privatization on electricity prices. They detect that privatization leads to lower electricity prices for industrial consumers. Using a fixed effects panel data model for 25 developing countries covering the period 1985-2001, Zhang, Parker and Kirkpatrick (2002) investigate the effects of privatization, competition and regulation reforms on electricity generation. They also test combined effects of regulation and competition and effects of regulation and privatization on electricity generation. The results of the study show that privatization per se is not associated with higher operating efficiency in terms of labor productivity. However, privatization leads to better capacity utilization. When there is a supportive independent regulatory authority in place, privatization will lead to higher output and thus stimulate economic growth. However, the effects of privatization on electricity prices are insignificant. 
A research by Zhang, Parker and Kirkpatrick (2008) about the effects of privatization, regulation and competition on efficiency in electricity generation activity, conducted on a sample of 36 transition and developing countries, came to similar conclusions. According to their results, regulatory reforms on their own are not sufficient to increase electricity generation. Moreover, if they are not conducted at the same time as other reforms, primarily unbundling and market liberalization, they can even worsen the performances of electricity generation companies. Therefore, regulatory quality is important, but has to be accompanied by other reforms. Furthermore, it demands independence and transparency of the regulatory body. They proved that competition and not privatization is a crucial element for efficiency improvement in the sector having a significant monopolistic/oligopolistic market structure. The data also shows that privatization is beneficial for growth only when it is followed by a quality regulation framework and existence of an independent regulator. Their main conclusion is that privatization and regulation on their own do not lead to improvements in economic performances and economic growth, even though there are some positive interactive effects. However, introducing competition is very efficient in stimulating improvements of economic performances.

Jamasb et al. (2004) analyzed a large number of studies looking at electricity market reforms in developing countries. These studies cover a wider range of variables than those tested in the EU-focused studies and address additional issues such as the role of wider institutional arrangements (outside the electricity sector), energy resource endowments (whether self-sufficiency encourages reform), the impact of reform on investments and energy losses and the role of privatization and independent regulation (Pollitt, 2007). Jamasb et al. (2004) summarize the econometric evidence contained in Wolak (1997), Zellner and Henisz (2000), Bacon and Besant-Jones (2001), Drillisch and Riechmann (1998), Holburn (2001), Siniscalo et al. (2001), Ruffin (2003), Bergara et al. (1997) and Zhang et al. (2002). (see Pollitt, 2007). According to Pollitt (2007), their main conclusions are:

1. Political and judicial institutions and energy resource endowments matter for reform progress, which means that wider economic, institutional and political environment is important.

2. Privatization improves efficiency if accompanied by independent regulation. Competition improves efficiency in generation, but independent regulator alone is not significant for efficiency and economic outcomes.

3. Privatization has no significant effect on prices; competition has a mixed effect, while regulation has no significant price effect.

4. Private investment that is beneficial for economic growth is stimulated by the strength of property rights protection and the presence of independent regulation. 
It should be noted that there has been limited cross-testing of most of the hypotheses across the studies, so further analysis is necessary to increase the reliability of the results. According to Jamasb et al. (2005), there is reason to question the robustness of some of the empirical findings as the comparability of the studies is constrained by variations in data and model specifications. It is hard to get a consistent picture of reform due to obstacles in comparability between different studies that use different data and methods. Even where there is a rather high degree of comparability, sensitivity of the findings to the choice and definition of variables and model specification, casts considerable uncertainty over the policy relevance of the existing body of knowledge.

\section{Methodology of analysis}

The methodology used in our research is based on panel data. Panel data has two dimensions: cross-sectional dimension representing individual country and time dimension (Wooldridge, 2003). According to Gujarati (2004) panel data sets take into account the heterogeneity in the cross-sectional units, give more informative data, less co-linearity among variables, more variability, more degrees of freedom and more efficiency. Panel data sets help to study the dynamics of change as it helps to study repeated cross-section of observations and therefore they are used to analyze the effects that cannot be observed in pure cross-section or pure timeseries data. These data sets minimize the bias that may result if individual units are aggregated into broad aggregates. In addition, the use of panel data also provides a means of reducing the problem caused by the omission of certain variables that are correlated with explanatory variables (Hsiao, 1999).

In this study the panel regression model with fixed effects was used. The fixedeffects model is a common choice among economists in cases when the model is evaluated based on the data which are not randomly chosen and where there is a high probability that each country has certain specific effects in correlation with regressors. As we are dealing with different country samples (developed and developing countries) and bigger time series, country and time effects should be included in the model. They should be included in form of a fixed-effects model when the focus is set on specific set of countries. On the other hand, a panel regression model with random effects is used when individual countries are chosen from a larger population (Jamasb et al. 2005).

The panel data consists of $N$-units and T-time periods, and therefore we have $N$ times $T$ observations. The classical linear regression model without the intercept is:

$$
Y_{i t}=\beta_{1} X_{i t 1}+\beta_{2} X_{i t 2}+\mu_{i t}
$$

for $i=1,2, \ldots, N$ and $t=1,2, \ldots, T$ 
where $Y_{i t}$ is the value of $\mathrm{Y}$ for the $i t h$ unit for the $t$ th time period; $X_{i t 1}$ is the value of $X_{1}$ for the $i t h$ unit for the $t$ th time period; $X_{i 2}$ is the value of $X_{2}$ for the $i t h$ unit for the $t$ th time period, and $\mu_{i t}$ is the error for the $i t h$ unit for the $t$ th time period.

The fixed-effects regression model, which is an extension of the classical linear regression model, is:

$$
Y_{i t}=\beta_{1} X_{i t 1}+\beta_{2} X_{i t 2}+v_{i}+\varepsilon_{i t}
$$

where $\mu_{i t}=v_{i}+\varepsilon_{i t}$. We have decomposed the error term for the classical linear regression model into two components. The component $v_{\mathrm{i}}$ represents all unobserved factors that vary across units but are constant over time. The component $\varepsilon_{i t}$ represents all unobserved factors that vary across units and time. We assume that the net effect on $Y$ of unobservable factors for the ith unit that are constant over time is a fixed parameter, designated $\alpha_{i}$. The fixed-effects parameters, $\alpha_{i}$, capture the net effects of all variables, both observable and unobservable, that differ across units but are constant over time. Therefore, in the fixed-effects model we cannot include any observable variable that differs across units but is constant over time. If we do, then we have perfect multicollinearity and we cannot obtain estimates of the parameters.

We formulate regression equations as below in order to analyze the impact of electricity industry reform on power sector efficiency:

$$
Y_{i t}=\beta_{1}+\Sigma \beta_{j} X_{j i t}+\Sigma \gamma_{p} Z_{p i}+\delta t+\varepsilon_{i t}
$$

where $i$ and $t$ represent unit of observation and time period, respectively; $j$ and $p$ are indices used to differentiate between observed and unobserved variables; $X_{j i}$ and Zpi represent observed and unobserved variables, respectively; $X_{j i}$ includes both reform variable and control variable; $Y_{i t}$ is dependent variable; $\varepsilon_{i t}$ is the disturbance term and $t$ is time trend term. It is impossible to obtaining information about the $\Sigma \gamma_{p} Z_{p i}$ because the Zpi variables are unobserved. We define a term $\alpha_{i}$, known as the unobserved effect, which represents the joint impact of the $Z_{p i}$ variables on $Y_{i t}$. Therefore our model can be written as follows:

$$
Y_{i t}=\beta_{1}+\Sigma \beta_{j} X_{j i t}+\alpha_{i}+\delta t+\varepsilon_{i t}
$$

According to Erdogdu (2011), the characterization of the $\alpha_{i}$ component is crucially important in the analysis. "If control variables are so comprehensive that they capture all relevant characteristics of the individual, there will be no relevant unobserved characteristics. In that case, the $\alpha_{i}$ term may be dropped and pooled data regression (OLS) may be used to fit the model, treating all the observations for all time periods as a single sample" (Erdogdu, 2011). Since we are not sure whether control variables in our models describe all relevant country characteristics, we cannot directly carry out a pooled data regression of $Y$ on $X$ because it would 
generate an omitted variable bias. In order to choose between two regression specifications, we apply the Hausmann test for fixed versus random effects. First, we estimate the fixed effects model (which is consistent) and then estimate the random-effects model (which is efficient). On a significance level of 5\%, Hausmann test indicates significant differences in the coefficients, so we decide to use fixed effects model.

\section{Data and empirical analysis}

The data used in our analysis is net electricity generation per capita (in GWh/ million people), net installed electricity generation capacity per capita (in GW/ million people), net electricity generation per employee (in $\mathrm{GWh} /$ million people) and electricity transmission and distribution losses (\% of output) as dependent variables. These four indicators represent the efficiency in electricity sector. According to Nepal and Jamasb (2012), per capita approximation is used in order to homogenize the effect of increasing population across all outcomes.

Net electricity generation per capita represents the first indicator of efficiency in electricity sector. This variable is calculated by dividing the net electricity generation by the total number of population in each country and each year. The data on net electricity generation and population are obtained by US Energy Information Administration (EIA, 2012) and World Bank (2012).

Net installed electricity generation capacity per capita represents the second indicator of efficiency in electricity sector. This measure is reflective of the capital investments devoted to electricity generation and expansion capacity. The variable is calculated by dividing the net installed electricity generation capacity by the total number of population in each country and each year. The data on net installed electricity generation capacity and population are obtained by US Energy Information Administration (EIA, 2012) and World Bank (2012).

The third indicator of efficiency in electricity sector is net electricity generation per employee in electricity sector. This indicator represents the labour productivity in electricity sector that comprises generation, transmission, distribution and supply of electricity. A higher net electricity generation per employee will lead to more efficient electricity sector. This variable is calculated by dividing the net electricity generation by the number of people employed in electricity sector. The data on net electricity generation are obtained by US Energy Information Administration (US EIA, 2012). The data on employment in electricity sector come from EU KLEMS database (2012).

Electricity transmission and distribution losses (\% of output) represent the last efficiency indicator in our analysis. Electricity transmission and distribution losses 
are network losses and include losses in transmission between sources of supply and points of distribution and in the distribution to consumers (US IEA, 2012). Any decrease in electricity transmission and distribution losses (\% of output) will lead to higher efficiency in electricity sector. The data on electricity transmission and distribution losses (\% of output) are obtained from the World Bank (2012).

Since our aim is to analyse the impact of electricity sector reforms on efficiency in electricity sector, we decided to construct explanatory (independent) variable by using the same methodology as Erdogdu (2011) and apply for a different group of countries. In order to construct the „electricity market reform“ variable which covers all key elements of reforms in electricity sector, we created 8 dummy variables that can take on the values from 0 to 8 , depending on the number of reform steps taken in each country and each year. Although there exist a wide variability in individual electricity sector reforms, they basically include the combination of these key elements of reforms (IADB, 2001; Joskow, 1998; Newberry, 2002): (1) introduction of independent power producers, (2) corporatization of stateowned enterprises, (3) law for electricity sector liberalisation, (4) introduction of unbundling, (5) establishment of an electricity market regulator, (6) introduction of privatization, (7) establishment of a wholesale electricity market and (8) choice of supplier. The dummy variables for reform steps were created by the authors based on the collected data from various international and national sources: OECD International Regulation Database (2015), Council of European Energy Regulators (2005; 2005a; 2005b), Energy Community Secretariat (2007; 2012; 2013; 2014), European Commission (2001; 2003; 2004; 2005; 2005a; 2009; 2010; 2011), Poyry and Nord Pool Consulting AS (2010) and Regional Centre for Energy Policy Research (2009).

We also tested the possible interactional effects of individual reform steps in electricity sector on electricity generation and electricity network losses. The following interactional variables are included in the model: (1) privatization and regulatory Agency; (2) privatization and unbundling and (3).regulatory agency and unbundling.

GDP per capita variable is used as a control variable and it represents a part of the country specific features that may have an influence on efficiency level in the electricity industry. Data on GDP per capita come from the World Bank (2012).

Tables 1 and 2 present the descriptive statistics, and normality test for level and first differenced variables. 
Table 1: Descriptive statistics of the variables in Model 1 (for EU-15)

\begin{tabular}{|l|r|r|r|r|c|}
\hline \multicolumn{1}{|c|}{ Variables } & Mean & \multicolumn{1}{c|}{$\begin{array}{c}\text { Standard } \\
\text { Deviation }\end{array}$} & Minimum & Maximum & $\begin{array}{c}\text { Number of } \\
\text { Observations }\end{array}$ \\
\hline \multicolumn{5}{|c|}{ Dependent Variables } \\
\hline $\begin{array}{l}\text { Net electricity } \\
\text { generation per capita }\end{array}$ & 7.091135 & .6910852 & 5.328518 & 9.592696 & 240 \\
\hline $\begin{array}{l}\text { Net installed generation } \\
\text { capacity per capita }\end{array}$ & 1.938428 & .1784281 & 1.444962 & 2.553249 & 240 \\
\hline $\begin{array}{l}\text { Net electricity } \\
\text { generation per } \\
\text { employee in electricity } \\
\text { sector }\end{array}$ & 4.037382 & .826799 & .7015252 & 6.537857 & 240 \\
\hline $\begin{array}{l}\text { Share of transmission } \\
\text { and distribution } \\
\text { electricity losses in } \\
\text { output (\%) }\end{array}$ & 6.572456 & 3.008035 & 1,1531681 & 39,07103825 & 240 \\
\hline $\begin{array}{l}\text { Electricity market } \\
\text { reform score }\end{array}$ & 5.379167 & 2.631033 & -.0583333 & 9.129167 & 240 \\
\hline $\begin{array}{l}\text { Privatization and } \\
\text { Regulator }\end{array}$ & .4791667 & .3937934 & -.3958333 & 1.166667 & 240 \\
\hline $\begin{array}{l}\text { Privatization and } \\
\text { Unbundling }\end{array}$ & .4625 & .4010316 & -.4125 & 1.15 & 240 \\
\hline $\begin{array}{l}\text { Unbundling and } \\
\text { Regulator }\end{array}$ & .6458333 & .4419787 & -.2291667 & 1.270833 & 240 \\
\hline GDP per capita & 10.30838 & .2829249 & 9.696869 & 10.87589 & 240 \\
\hline
\end{tabular}

Source: Authors

The dataset covered in the analysis includes a sample of all EU Member States in which the electricity market reform process has been initiated. The economic effects of the electricity sector reforms on electricity generation and electricity transmission and distribution losses are analyzed for two groups of countries: the EU-15 (old EU Member States) and the EU-12 (new EU Member States) and selected Southeast European countries. 
Nela Vlahinić Lenz, Vedran Prša $\bullet$ Growth potential of energy sector reforms...

Table 2: Descriptive statistics of the variables in Model 1 (for EU-12 and selected SEE countries)

\begin{tabular}{|c|c|c|c|c|c|}
\hline Variables & Mean & $\begin{array}{c}\text { Standard } \\
\text { Deviation }\end{array}$ & Minimum & Maximum & $\begin{array}{c}\text { Number of } \\
\text { Observations }\end{array}$ \\
\hline \multicolumn{6}{|c|}{ Dependent Variables } \\
\hline $\begin{array}{l}\text { Net electricity } \\
\text { generation per capita }\end{array}$ & 4.139673 & .464603 & 2.817977 & 6.459713 & 208 \\
\hline $\begin{array}{l}\text { Net installed generation } \\
\text { capacity per capita }\end{array}$ & 1.044113 & .1692366 & .5099791 & 1.892792 & 208 \\
\hline $\begin{array}{l}\text { Net electricity } \\
\text { generation per } \\
\text { employee in electricity } \\
\text { sector }\end{array}$ & 1.296591 & .3086592 & .1557117 & 2.448997 & 208 \\
\hline $\begin{array}{l}\text { Share of transmission } \\
\text { and distribution } \\
\text { electricity losses in } \\
\text { output }(\%)\end{array}$ & 12.88576 & 5.057353 & 3,012997243 & 72,9020979 & 208 \\
\hline \multicolumn{6}{|c|}{ Explanatory Variables } \\
\hline $\begin{array}{l}\text { Electricity market } \\
\text { reform score }\end{array}$ & 4.230769 & 2.201651 & -1.615385 & 7.615385 & 208 \\
\hline $\begin{array}{l}\text { Privatization and } \\
\text { Regulator }\end{array}$ & .3605769 & .3437611 & -.5625 & 1.206731 & 208 \\
\hline $\begin{array}{l}\text { Privatization and } \\
\text { Unbundling }\end{array}$ & .3125 & .3806935 & -.3798077 & 1.158654 & 208 \\
\hline $\begin{array}{l}\text { Unbundling and } \\
\text { Regulator }\end{array}$ & .5240385 & .4471305 & -.2451923 & 1.139423 & 208 \\
\hline \multicolumn{6}{|c|}{ Control Variables } \\
\hline GDP per capita & 8.78551 & .4746093 & 7.880023 & 9.742519 & 208 \\
\hline
\end{tabular}

Source: Authors

The data set for the EU-15 countries is based on a panel of the following 15 countries: Belgium, Denmark, Germany, Ireland, Spain, France, Italy, Luxembourg, Netherlands, Austria, Portugal, Finland, Sweden, Greece and United Kingdom. The EU-12 countries include: the Czech Republic, Estonia, Cyprus, Latvia, Lithuania, Hungary, Malta, Poland, Slovenia, Slovakia, Romania and Bulgaria. The selected SEE countries included in the model are: Croatia, Bosnia and Herzegovina, FYR Macedonia and Albania. Due to the lack of data for the period 1998-2005, Serbia and Montenegro are not included (Montenegro became independent from Serbia in 2006). The data set for the EU-12 and selected SEE is based on a panel of 16 countries. In total our data set is based on a panel of 31 countries.

The time period used in the analysis is 1995 - 2010 for the EU-15 countries and 1998 - 2010, due to the unavailability of data, for the EU-12 and selected SEE countries. 
We are aware that the analysis would be far more robust if a longer time span was available, especially for Southeast European countries, but this was impossible due to the lack of the data on electricity sector reforms. Generally, data availability shapes the content and manner of addressing research questions. Another common difficulty is how to represent qualitative aspects of reform such as institutional factors or market structure characteristics. Since these aspects are difficult to define and measure directly and objectively, a common approach has been to use proxies in the form of indices and categorical variables (Jamasb et al., 2005).

As it has been mentioned, the analysis has been done for the EU-15 and the EU-12 and selected Southeast European countries. The research results for the EU-15 are presented in Table 3.

Table 3: The impact of energy sector reforms on electricity generation and electricity transmission and distribution losses in the EU-15

\begin{tabular}{|c|c|c|c|c|}
\hline $\begin{array}{l}\text { Dependent } \\
\text { variables }\end{array}$ & $\begin{array}{l}\text { Net electricity } \\
\text { generation per } \\
\text { capita }\end{array}$ & $\begin{array}{l}\text { Net installed } \\
\text { electricity } \\
\text { generation } \\
\text { capacity per } \\
\text { capita } \\
\end{array}$ & $\begin{array}{l}\text { Net electricity } \\
\text { generation per } \\
\text { employee in the } \\
\text { electricity sector }\end{array}$ & $\begin{array}{l}\text { Electric power } \\
\text { transmission } \\
\text { and distribution } \\
\text { losses } \\
\text { (\% of output) }\end{array}$ \\
\hline \multicolumn{5}{|c|}{ Explanatory variables } \\
\hline $\begin{array}{l}\text { Electricity market } \\
\text { reform variable }\end{array}$ & $\begin{array}{r}0.098 \\
(2.72)^{* * *}\end{array}$ & $\begin{array}{r}0.029 \\
(3.91)^{* * *} \\
\end{array}$ & $\begin{array}{r}0.169 \\
(4.75)^{* * * *} \\
\end{array}$ & $\begin{array}{r}-0.28 \\
(-1.67)^{*}\end{array}$ \\
\hline $\begin{array}{l}\text { Privatization and } \\
\text { Regulator }\end{array}$ & $\begin{array}{r}0.496 \\
(2.17)^{* * * *}\end{array}$ & $\begin{array}{r}0.102 \\
(2.18)^{* * *}\end{array}$ & $\begin{array}{r}0.049 \\
(0.22)\end{array}$ & $\begin{array}{r}-4.65 \\
(-4.36)^{* * *}\end{array}$ \\
\hline $\begin{array}{l}\text { Privatization and } \\
\text { Unbundling }\end{array}$ & $\begin{array}{r}-0.374 \\
(-1.58) \\
\end{array}$ & $\begin{array}{r}-0.092 \\
(-1.90)^{*} \\
\end{array}$ & $\begin{array}{l}-0.036 \\
(-0.15) \\
\end{array}$ & $\begin{array}{r}3.64 \\
(3.29)^{* * *} \\
\end{array}$ \\
\hline $\begin{array}{l}\text { Unbundling and } \\
\text { Regulator }\end{array}$ & $\begin{array}{r}-0.176 \\
(-0.88) \\
\end{array}$ & $\begin{array}{r}-0.08 \\
(-1.96)^{*} \\
\end{array}$ & $\begin{array}{r}-0.29 \\
(-1.48) \\
\end{array}$ & $\begin{array}{r}1.652 \\
(1.77)^{*} \\
\end{array}$ \\
\hline GDP per capita & $\begin{array}{r}0.58 \\
(2.86)^{* * * *}\end{array}$ & $\begin{array}{r}0.329 \\
(7.94)^{* * *}\end{array}$ & $\begin{array}{r}1.080 \\
(5.43)^{* * * *}\end{array}$ & $\begin{array}{r}-2.094 \\
(-2.22)^{* * *}\end{array}$ \\
\hline Constant & $\begin{array}{r}0.671 \\
(0.33) \\
\end{array}$ & $\begin{array}{r}-1.568 \\
(-3.80)^{* * *} \\
\end{array}$ & $\begin{array}{r}-7.826 \\
(-3.96)^{* * *} \\
\end{array}$ & $\begin{array}{r}29.156 \\
(3.10)^{* * *} \\
\end{array}$ \\
\hline $\begin{array}{l}\text { Number of } \\
\text { Observations }\end{array}$ & 240 & 240 & 240 & 240 \\
\hline R2 & 0.28 & 0.54 & 0.51 & 0.17 \\
\hline
\end{tabular}

Note: Coefficient is significant at the ${ }^{* * *} 1 \%$ level, ${ }^{* *} 5 \%$ level, ${ }^{*} 10 \%$ level

Source: Authors' calculations

The research results show that energy market reforms in the EU-15 (electricity market reform variable) have a significantly positive impact on net electricity generation per capita, net installed electricity generation capacity per capita and net electricity generation per employee in the electricity sector. Moreover, energy market reforms in the EU-15 have a significant impact on the reduction of electricity transmission and distribution losses. 
The interaction variable 'privatization and regulator' has a significantly positive impact on net electricity generation per capita, net installed electricity generation capacity per capita as well as on the reduction of transmission and distribution losses.

However, the interaction variable 'privatization and unbundling' has a significantly negative impact on net installed electricity generation capacity per capita and a significant impact on the increase of transmission and distribution losses. Similarly, the interaction variable 'unbundling and regulator' has also a significantly negative impact on net installed electricity generation capacity per capita and a significant impact on the increase of transmission and distribution losses.

In line with our expectations, GDP per capita has a significantly positive impact on net electricity generation per capita, net installed electricity generation capacity per capita and net electricity generation per employee in the electricity sector and it also has a significant impact on the reduction of electricity transmission and distribution losses.

Table 4 presents the empirical results for the EU-12 and selected Southeast European countries.

Table 4: The impact of energy sector reforms on electricity generation and electricity transmission and distribution losses in the EU-12 and selected Southeast European countries

\begin{tabular}{|c|c|c|c|c|}
\hline $\begin{array}{l}\text { Dependent } \\
\text { variables }\end{array}$ & $\begin{array}{l}\text { Net electricity } \\
\text { generation per } \\
\text { capita }\end{array}$ & $\begin{array}{l}\text { Net installed } \\
\text { electricity } \\
\text { generation } \\
\text { capacity per } \\
\text { capita }\end{array}$ & $\begin{array}{l}\text { Net electricity } \\
\text { generation per } \\
\text { employee in the } \\
\text { electricity sector }\end{array}$ & $\begin{array}{l}\text { Electric power } \\
\text { transmission } \\
\text { and distribution } \\
\text { losses } \\
\text { (\% of output) }\end{array}$ \\
\hline \multicolumn{5}{|c|}{ Explanatory variables } \\
\hline $\begin{array}{l}\text { Electricity market } \\
\text { reform variable }\end{array}$ & $\begin{array}{r}0.119 \\
(3.26)^{* * * *}\end{array}$ & $\begin{array}{r}0.058 \\
(3.89)^{* * *}\end{array}$ & $\begin{array}{r}0.091 \\
(4.35)^{* * * *}\end{array}$ & $\begin{array}{r}0.376 \\
(0.80)\end{array}$ \\
\hline $\begin{array}{l}\text { Privatization and } \\
\text { Regulator }\end{array}$ & $\begin{array}{r}0.016 \\
(0.10) \\
\end{array}$ & $\begin{array}{r}-0.115 \\
(-1.67)^{*}\end{array}$ & $\begin{array}{r}-0.115 \\
(-1.19) \\
\end{array}$ & $\begin{array}{l}-1.043 \\
(-0.49)\end{array}$ \\
\hline $\begin{array}{l}\text { Privatization and } \\
\text { Unbundling }\end{array}$ & $\begin{array}{r}-0.236 \\
(-1.45)\end{array}$ & $\begin{array}{l}-0.027 \\
(-0.41)\end{array}$ & $\begin{array}{r}0.075 \\
(0.79)\end{array}$ & $\begin{array}{r}1.056 \\
(0.51)\end{array}$ \\
\hline $\begin{array}{l}\text { Unbundling and } \\
\text { Regulator }\end{array}$ & $\begin{array}{r}0.031 \\
(0.24) \\
\end{array}$ & $\begin{array}{r}-0.150 \\
(-2.77)^{* * * *}\end{array}$ & $\begin{array}{r}-0.264 \\
(-3.48)^{* * * *} \\
\end{array}$ & $\begin{array}{l}-1.442 \\
(-0.86)\end{array}$ \\
\hline GDP per capita & $\begin{array}{r}0.091 \\
(0.65) \\
\end{array}$ & $\begin{array}{l}-0.013 \\
(-0.23) \\
\end{array}$ & $\begin{array}{r}0.248 \\
(3.03)^{* * *}\end{array}$ & $\begin{array}{l}-2.958 \\
(-1.63) \\
\end{array}$ \\
\hline Constant & $\begin{array}{r}2.880 \\
(2.54)^{* * *} \\
\end{array}$ & $\begin{array}{l}1.041 \\
(2.22)^{* *}\end{array}$ & $\begin{array}{c}-1.115 \\
(-1.70)^{*}\end{array}$ & $\begin{array}{r}38.085 \\
(2.62)^{* * *}\end{array}$ \\
\hline $\begin{array}{l}\text { Number of } \\
\text { Observations }\end{array}$ & 240 & 240 & 240 & 240 \\
\hline R2 & 0.315 & 0.121 & 0.481 & 0.054 \\
\hline
\end{tabular}

Note: Coefficient is significant at the ${ }^{* * *} 1 \%$ level, ${ }^{* *} 5 \%$ level, ${ }^{*} 10 \%$ level.

Source: Authors' calculation 
Although energy sector reforms in the EU-12 and other selected countries in Southeast Europe ('electricity market reform' variable) have a significantly positive impact on net electricity generation per capita, net installed electricity generation capacity per capita and net electricity generation per employee in the electricity sector, the reforms results are not positive regarding electricity transmission and distribution losses. GDP per capita, as a control variable, has a significantly positive impact on net electricity generation per employee in the electricity sector.

\section{Results and discussion}

The obtained results show that the unbundling of electricity activities in interaction with privatization and regulatory agency is not necessarily associated with the increase in electricity generation efficiency. On the other hand, the unbundling of electricity activities in interaction with privatization and the regulatory agency may have a negative impact on efficiency indicators in electricity generation. As we have expected, the research results show that there are important differences between old Member States on one hand (EU-15) and new EU Member States and Southeast European countries on the other. According to our results, in less developed countries the unbundling in interaction with privatization and the regulatory agency increase the level of electricity transmission and distribution losses. Although the unbundling of activities in energy sector is the necessary step in reform process of all EU Member States, it seems that it could have negative consequences for industry efficiency in case of small and less developed energy systems. Several factors are in favor of the integration of electricity segments. First, a common ownership of electricity activities enables minimization of costs far more than when these are unbundled. Secondly, vertically integrated generation and transmission simplify the link between the investments in electricity generation capacities and the return on invested assets. It is worth mentioning that the investments in the electricity sector are specific, as there is a high level of uncertainty of asset return. This is the case with narrowly specialized investments where there is almost no possibility of changing their purpose. Consequently, the investors are interested to invest only if their investment is secured, either in form of a long-term delivery arrangement or unique company model. In the case of electricity generation and distribution there are two additional factors in favor of integration: investment planning and urgent interventions in electricity supply for consumers.

Since unbundling of the system tends to increase transaction costs and loss of economies of coordination, the net effect is uncertain in the absence of independent regulatory oversight. The effectiveness of competition and incentive regulation will determine whether the benefits of the reform will exceed the higher transaction costs in order to produce net performance improvements (Jamasb et al., 2005). The reason lies in the fact that economic and political institutions which are necessary 
for a proper functioning of the regulatory bodies are still underdeveloped in most transition countries. It seems that reforms per se cannot improve structural problems without stabile and incentive macroeconomic environment and institutional framework. Regulatory agencies are also faced with the lack of qualified human, administrative and know-how resources. Their complete independence is questionable as the government still has a formal or informal impact on them, particularly in those activities that are related to electricity prices. Another issue is the informal influence of the regulated industry, in regards to the high concentration of staff coming from the electricity industry, which put regulators in a bad position. Therefore, the regulation can even lose its initial purpose and instead of protecting the consumers, it starts protecting the regulated industry.

Negative results of energy sector reforms in less developed countries (EU-12 and selected Southeast European countries) are also related to specific problems in those economies: economic losses due to financial indiscipline and inadequate collection of bills, especially in Southeast European countries, and technical losses as a consequence of old technology, especially in distribution networks.

Based on the obtained results, it can be concluded that the reform processes in energy sector that encompasses regulatory reforms, restructuring, liberalization and privatization has been far more difficult for transition countries than for developed old EU Member States. It is a consequence of the fact that their electricity systems entered the reform process with a significantly negative heritage and have been faced with macroeconomic and institutional constraints. Since the impact of these reform steps on electricity generation and transmission and distribution losses is negative, it implies that the uniform EU reform energy model cannot be incentive for economic activity in all countries and can even hamper their economic growth. Therefore it is reasonable to question the uniform EU reform model because it is obviously not appropriate for all countries since it requires adequate level of institutional resources that are missing in most transition and some post-transition countries.

\section{Conclusion}

The results of the research show that the hypothesis has proved to be true. The findings show that unlike in the EU-15 countries, energy sector reforms in the EU-12 and selected Southeast European countries have no significant impact on electricity transmission and distribution losses. Even more, when the interaction variables were applied, the results show that the unbundling of electricity activities in interaction with privatization and regulatory agencies have a negative impact on efficiency indicators in electricity generation and even increase transmission and distribution losses. Although a positive correlation between electricity generation 
and economic growth has been proved in many studies, nevertheless one could conclude that energy sector reforms have not been beneficial for economic activity and GDP growth in transition and post-transition economies. It could mean that the EU reform model in energy sector is not appropriate for all Member States because it requires appropriate level of institutional resources in order to benefit from it. Of course the obtained results do the certain contribution to the economic literature. However, we are aware of some limitations of this research that we acknowledge. Like all other econometric studies on electricity reform, the issue of endogeniety may be raised in our study too. It is likely that just as reform process has an effect on electricity generation efficiency indicators, electricity generation can also affect reform decisions. Another limitation is the short time period available for EU-12 and Southeast European countries and questionable quality of data in the early '90. In the future it may be interesting to investigate the relationship between industrial characteristics and reform results in electricity sector because, contrary to the theory, countries with highly developed industrial sector are not prone to conduct unbundling and liberalization. Despite these limitations this is, as far as is known, the first systematic analysis of energy reform results in transition countries of Southeast Europe in a wider European framework. The results we obtained could have important consequences for economic and energy policy in light of the ongoing desire to increase electricity generation, improve efficiency and stimulate economic growth. Policy makers should implement such a reform model that would boost energy production and its efficiency and enhance sustainable economic growth that would be based on domestic rather than imported energy.

\section{References}

Barro, R. J. (1997) Determinants of Economic Growth: A cross-country empirical study, Development Discussion Paper No. 579, Cambridge, MA: Harvard Institute for International Development.

Bayraktutan, Y., Yilgör, M., Uçak, S. (2011) "Renewable Electricity Generation and Economic Growth: Panel-Data Analysis for OECD Members", International Research Journal of Finance and Economics, No. 66, pp. 59-66.

Bergara, M., Henisz, W. J., Spiller, P.T. (1997) Political Institutional and Electric

Utility Investment: A Cross-Nation Analysis, Barkeley: University of California Energy Institute, Program on Workable Energy Regulation (POWER), Working Paper No. PWP-052, doi: 10.2307/41165931.

Bortolotti, B., Fantini, M., Siniscalco, D. (1998) Regulation and Privatisation: the Case of Electricity, Turin: University of Turin, Working Paper, Department of Economics and Finance.

Council of European Energy Regulators (2005) Data Annex to the Regulatory Benchmarking Report for South East Europe, Brussels. 
Council of European Energy Regulators (2005a) Regulatory Benchmarking Report for South East Europe, Brussels.

Council of European Energy Regulators (2005b) CEER Regulatory Benchmark Report 2005, Brussels.

Drillisch, J., Riechmann, C. (1998) Liberalisation of the Electricity Supply Industry - Evaluation of Reform Policies, Cologne/ Tokyo: EWI Working Paper No. 98/5.

Energy Community Secretariat (2007) Benchmarking and Compliance Reports, Vienna.

Energy Community Secretariat (2012) Annual Report on the Implementation of the Acquis under the Treaty establishing the Energy Community, Vienna.

Energy Community Secretariat (2013) Annual Implementation Report, Vienna.

Energy Community Secretariat (2014) Annual Implementation Report, Vienna.

Erdogdu, E. (2011) „What happened to efficiency in electricity industries after reforms?", Energy Policy, Vol. 39, No. 10, pp. 6551-6560, doi: 10.1016/j. enpol.2011.07.059.

EU (2012) EU KLEMS Database, European Union.

European Commission (2001) First benchmarking report on the implementation of the internal electricity and gas market, Brussels: Commission staff working paper, SEC (2001) 1957.

European Commission (2003) Second benchmarking report on the implementation of the internal electricity and gas market, Brussels: Commission staff working paper, SEC (2003) 448.

European Commission (2004) Third benchmarking report on the implementation of the internal electricity and gas market, Brussels: DG TREN draft working paper.

European Commission (2005) Implementing the internal energy market, Brussels: Annual report.

European Commission (2005a) Technical Annexes to the Report from the Commission on the Implementation of Gas and Electricity Internal Market, Brussels: Commission Staff Working Document, SEC (2004) 1720.

European Commission (2009) Report on Progress in Creating the Internal Gas and Electricity Market, Technical Annex to the Communication from Commission to the Council and the European Parliament, Brussels: DG TREN Staff Working Document, SEC (2009) 287.

European Commission (2010) Report on progress in creating the internal gas and electricity market, Technical Annex to the Communication from the Commission to the Council and the European Parliament, Brussels: SEC (2010) 251 final.

European Commission (2011) 2009-2010 Report on Progress in Creating the Internal Gas and Electricity Market, Technical Annex, Brussels: Commission Staff Working Paper. 
Ghosh, S. (2009) "Electricity supply, employment and real GDP in India: evidence from cointegration and Granger-causality test", Energy Policy, Vol. 37, No. 8, pp. 2926-2929, doi: 10.1016/j.enpol.2009.03.022.

Gujarati, D.N. (2004) Basic Econometrics, Fourth Edition, McGraw Hill.

Gupta, J.P., Sravat, A. K. (1998) "Development and Project Financing of Private Power Projects in Developing Countries: a case study of India", International Journal of Project Management, Vol. 16, No. 2, pp. 99-105, doi: 10.1016/ S0263-7863(97)00030-6.

Hall, R.E., Jones, C. (1999) "Why Do Some Countries Produce So Much More Output per Worker than Others?", Quarterly Journal of Economics, Vol. 114, No. 1, pp. 83-116, doi: 10.1162/003355399555954.

Hattori, T., Tsutsui, M. (2004) "Economic Impact of Regulatory Reforms in the Electricity Supply Industry: A Panel Data Analysis for OECD Countries", Energy Policy, Vol. 32, No. 6, pp.823-832, doi: 10.1016/S0301-4215(03)00004-1.

Holburn, G.F. (2001) "Political Risk, Political Capabilities and International Investment Strategy: Evidence from the Power Generation Industry" paper presented at the $5^{\text {th }}$ Annual EUNIP Conference, Vienna, 29 November -1 December 2001.

Hsiao, C. (1999) Analysis of Panel Data, New York: Cambridge University Press.

IADB (2001) Competitivness: The Business of Growth, Economic and Social Program in Latin America, 2001 Report, Research Department, Inter-American Development Bank (IADB), Washington, D.C.

Jalilian, H., Kirkpatrick, C. Parker, D. (2007) The Impact of Regulation on Economic Growth in Developing Countries: A Cross-Country Analysis", World Development, Vol. 35, No. 1, pp. 87-103, doi: 10.1016/j.worlddev.2006.09.005.

Jamasb, T., Newbery, D., Pollitt, M. (2004) Core Indicators for Determinants and Performance of Electricity Sector Reform in Developing Countries, Cambridge: Working Papers in Economics, doi: 10.1596/1813-9450-3599.

Jamasb, T. et al. (2005) Electricity Sector Reform in Developing Countries: A Survey of Empirical Evidence on Determinants and Performance, Washington D.C.: World Bank Policy Research Working Paper 3549, doi: 10.1596/18139450-3549.

Joskow, P.L. (1998) "Electricity Sectors in Transition", Energy Journal, Vol. 19, No. 2, pp. 25-52.

Kauffman, D., Kraay, A. (2002) Growth Without Governance, mimeo, Washington DC: World Bank, doi: 10.1353/eco.2002.0016.

Laffont, J. J., Tirole, J. (1993) A Theory of Incentives in Procurement and Regulation, Cambridge: The MIT Press.

Lean, H.H., Smyth, R. (2010) "Multivariate Granger causality between electricity generation, exports, prices and GDP in Malaysia", Energy, Vol. 35, No. 9, pp. 3640-3648, doi: 10.1016/j.energy.2010.05.008. 
Morimoto, R., Hope, C. (2004) "The impact of electricity supply on economic growth in Sri Lanka", Energy Economics, Vol. 26, No. 1, pp. 77-85, doi: 10.1016/s01409883(03)00034-3.

Nagayama, H. (2007) "Effects of regulatory reforms in the electricity supply industry on electricity prices in developing countries", Energy Policy, Vol. 35, No. 6, pp. 3440-3462, doi: 10.1016/j.enpol.2006.12.018.

Nagayama, H. (2009) "Electric power sector reform liberalization models and electric power prices in developing countries: An empirical analysis using international panel data", Energy Economics, Vol. 31, No. 3, pp. 463-472, doi: 10.1016/j.eneco.2008.12.004.

Nepal, R., Jamasb, T. (2012) "Reforming the Power Sector in Transition: Do Institutions Matter", Energy Economics, Vol. 34, No. 5, pp. 1675-1682, doi: 10.1016/j.eneco.2012.02.002.

Newberry, D.M. (2002) Issues and Options for Restructuring Electricity Supply Industries, Working Paper CMI EP No. 01/DAE No. 0210, Department of Applied Economics, University of Cambridge, Cambridge.

OECD (2015) International Regulation Database - Sector regulation// http://www. oecd.org/eco/reform/indicatorsofproductmarketregulationhomepage.html (20.4.2015).

Olson, M., Sarna, N., Swamy, A.V. (1998) Governance and Growth: A simple hypothesis explaining cross-country differences in productivity, mimeo, University of Maryland: Centre for Institutional Reform and Informal Sector (IRIS).

Pollitt, M. (2007) Evaluating the evidence on electricity reform: Lessons for the South East Europe (SEE) market, ESRC Electricity Policy Research Group and Judge Business School, University of Cambridge// https://www.repository.cam. ac.uk/bitstream/handle/1810/195425/0756\%26EPRG0725.pdf? sequence $=1$ (16.3.2015).

Pöyry and Nord Pool Consulting AS (2010) South East Europe Wholesale Market Opening, Final Report// https://www.energy-community.org/pls/portal/ docs/594181.PDF (10.2.2015).

Regional Centre for Energy Policy Research (2009) Electricity Post-Privatization: Initial Lessons Learned in South East Europe, Corvinus University of Budapest: February 6, 2009.

Sarker, A.R., Alam, K. (2010) "Nexus between electricity generation and economic growth in Bangladesh", Asian Social Science, Vol. 6, No. 12, pp. 16-22, doi: 10.5539/ass.v6n12p16.

Siniscalco, D., Bortolotti, B., Fantini, M. (2001) "Regulation and Privatisation: The Case of Electricity" In: Amato, G., Laudati, L.L. (eds.) The Anticompetitive Impact of Regulation, Cheltenham: Edward Elgar. 
Steiner, F. (2001) Regulation, Industry Structure and Performance in the Electricity Supply Industry, OECD Economic Studies No. 32, Paris.

Thomas, S. (2006) Recent evidence on the impact of electricity liberalisation on consumer prices, Public Services International Research Unit (PSIRU).

US EIA (2012) International Energy Statistics, US Energy Information Administration.

Wolak, F. (1997) Market Design and Price Behaviour in Restructured Electricity Markets: An International Comparison, Working Paper No. PWP-051, Program on Workable Energy Regulation (POWER), Barkley: University of California Energy Institute, doi: 10.1007/978-1-4615-4529-3_8.

World Bank (2012) World Development Indicators, Washington, D.C.

Reference Wooldridge, J. M. (2003) Introductory Econometrics: A Modern Approach, Canada: Cengage Learning.

Yoo, S.-H., Kim, Y. (2006) "Electricity generation and economic growth in Indonesia", Energy, Vol. 31, No. 4, pp. 2890-2899, doi: 10.1016/j.energy.2005.11.018.

Zeshan, M. (2013) "Finding the cointegration and causal linkages between the electricity production and economic growth in Pakistan", Economic Modelling, No. 31, pp. 344-350, doi: 10.1016/j.econmod.2012.11.021.

Zhang, Y.-F., Parker, D., Kirkpatrick, C. (2002) Electricity Sector Reform in Developing Countries: an Econometric Assessment of the Effects of Privatisation, Competition and Regulation, Working Paper No. 31, Centre on Regulation and Competition, Institute for Development Policy and Management, University of Manchester.

Zhang, Y.-F., Parker, D., Kirkpatrick, C. (2008) "Electricity sector reform in developing countries: an econometric assessment of the effects of privatization, competition and regulation", Journal of Regulatory Economics, Vol. 33, No. 2, pp. 159-178, doi: 10.1007/s11149-007-9039-7. 


\title{
Potencijalni učinak reformi u energetskom sektoru na ekonomski rast: Novi dokazi o proizvodnji električne energije u EU i zemljama jugoistočne Europe $^{1}$
}

\author{
Nela Vlahinić Lenz ${ }^{2}$, Vedran Prša ${ }^{3}$
}

\begin{abstract}
Sažetak
Cilj ovog rada je istražiti učinak reformi u energetskom sektoru na proizvodnju električne energije, a time $i$ na ekonomski rast u zemljama EU i jugoistočne Europe. Rad želi pojasniti postoje li razlike u učincima reformi na proizvodnu efikasnost po zemljama s obzirom na dostignuti stupanj razvoja i regionalne karakteristike. Naša je hipoteza da EU reformski model nije odgovarajući za sve zemlje članice EU i zemlje jugoistočne Europe jer ne povećava efikasnost proizvodnje u svim zemljama te stoga može ugroziti ekonomski rast. Za testiranje navedene hipoteze koristi se panel regresijski model s fiksnim učincima. Rezultati istraživanja pokazuju da za razliku od EU-15 (stare zemlje članice), reforme u energetskom sektoru u EU-12 (nove zemlje članice) i izabranim zemljama jugoistočne Europe (ugovorne strane Energetske Zajednice) nemaju signifikantan učinak na gubitke u prijenosnoj i distribucijskoj mrě̌i. Ovi rezultati upućuju na zaključak da jedinstveni EU reformski model nužno ne unapređuje efikasnost u djelatnosti proizvodnje električne energije u manje razvijenim zemljama. Čak štoviše, može ugroziti ekonomski rast te stoga ne može biti prihvatljiv u svim zemljama članicama. Razlog leži u činjenici da uspješan model reformi zahtijeva odgovarajuću razinu institucionalnih resursa koji još uvijek nisu zadovoljavajući u većini tranzicijskih i post-tranzicijskih zemalja.
\end{abstract}

Ključne riječi: reforme u energetskom sektoru, proizvodnja električne energije, ekonomski rast, gubitci u prijenosu i distribuciji, EU, jugoistočna Europa

JEL klasifikacija: Q43, Q48, L94, 98

1 Ovaj rad je financirala Hrvatska zaklada za znanost projektom broj IP-2013-11-2203i Sveučilište u Rijeci projektom broj 13.02.1.3.05.

2 Redoviti profesor, Sveučilište u Rijeci, Ekonomski fakultet, I. Filipovića 4, 51000 Rijeka, Hrvatska. Znanstveni interes: makroekonomija, ekonomija energetike. Tel.: +38551355111. E-mail: nela@efri.hr. Web stranica: https://www.efri.uniri.hr/personnel/redoviti-profesor/ vlahinic-lenz-nela.

3 Doktor ekonomskih znanosti, JP Elektroprivreda BiH - "Elektrodistribucija” Bihać, Krupska bb, 77000 Bihać, Bosna i Hercegovina. Znanstveni interes: ekonomija energetike. Tel.: +387 37 226 308.E-mail:vedranpra@yahoo.com. 
